\title{
Chapter Three
}

\section{Land, Customary and Non-Customary, in East New Britain}

\section{Keir Martin}

The Gazelle Peninsula of East New Britain (ENB) Province has for many years been regarded as one of Papua New Guinea's (PNG's) most 'developed' regions, with the village of Matupit being seen as one of the most forward-looking Tolai villages. It was the village closest to the town of Rabaul, and by the 1970s was regarded by many as one of its suburbs. Matupit was one of the most prosperous villages in PNG, where Tolai people enjoyed a peri-urban lifestyle and, by PNG standards, a comfortable standard of living. This prosperity was paid for by wage labour in town and the cash cropping that the Tolai had successfully developed on their customary land. This paper builds on previous anthropological research that has addressed business and change in the Gazelle (T.S. Epstein 1968; A.L. Epstein 1969; Salisbury 1970; Bradley 1982; Fingleton 1985), by describing tendencies that have emerged or come to new resolutions in the resettlement and reconstruction process following the volcanic eruptions of 1994. It will examine how ongoing debates about customary land within recent economic conditions were re-framed by Tolai in the new environment that they found themselves in after the eruption. In policy debates over the reform of customary land tenure in Melanesia, definitions of 'custom' are often left unclear or do not cover all of the potential meanings of the word. But what even a brief overview of patterns of land disputes at Matupit demonstrates is the number of different ways that the word 'custom' or its Tok Pisin equivalent kastom is used at a grass-roots level, forcing us to pay attention to the uses we make of key concepts in the course of such debates.

Despite the prosperity, pressures were already developing in the time leading up to the volcanic eruption. In contrast to the situation recorded by Smith and Salisbury (1961), in which intra-Tolai land litigation was rare, by the early 1990s ENB was among the leading provinces in the country in terms of the number of registered land disputes. In particular there was a growing tension between the matrilineal landholding clan and the increasingly important nuclear family. Fathers wanted to ensure that investments made on clan land passed to their

1 See Bradley (1982: 191-200) or Fingleton (1985: 58-9) regarding the increasing importance of the nuclear family in Tolai life. 
children rather than to their clan nephews. Customary land came to be seen in many contexts as a problem, and people were reluctant in many cases to build new developments on it. When the ENB Provincial Government offered up five agricultural blocks for lease to individuals before the eruption in 1994, they were amazed to find that there were thousands of applicants. The problem, according to John Brown, the then Advisor to the ENB Lands Division, was that 'people felt as if they had no rights to customary land' (Post-Courier 12 August 1999).

\section{Free from Custom? Land at Sikut}

Matupit, as the Tolai village with the highest population density and the most extensive economic development, suffered more than most from these problems. Many people described the eruption to me as a 'blessing from God', as the village was about to explode under the pressure of disputes. It is this irony that drew my attention - namely, that a disaster could be a divine intervention that would transform conflictive social relations. The disaster is said to be the main reason for the decrease in disputes, as many Matupi moved to a resettlement area at Sikut, an area of government land alienated from the Baining people during the colonial period. Around 200 Matupi families were each given blocks of around three hectares. The government is adamant that this land is not 'customary' land, meaning that it is to be owned by individual families, not by clans, and that each block will be inherited as property by the children of the title holder (in most cases the husband in a nuclear family unit). This position is, on the surface, supported by the majority of those Matupi who have relocated to Sikut. I was struck by the number of occasions on which Sikut residents told me that the land at Sikut was 'better' than Matupit land, not because it was more productive or plentiful, but because it was not 'customary' land. They described themselves as being 'free' from problems associated with customary ground. On these blocks they could work hard and pass on the benefits to their children.

However, just because the land at Sikut is not 'customary', this does not mean it is free from dispute. Rather, most disputes at present have a new character, causing divisions between some blockholders and those still waiting for blocks. Those waiting for blocks are housed on a small area of land euphemistically referred to as the 'care centre', living in shacks that have been erected out of old pieces of corrugated iron, wood, and even cardboard. People awaiting blocks have been temporarily allocated just under one hectare of land per family for gardening, but have been forbidden from planting cash crops because this land has been earmarked for future use as a centre for commercial activities and government services. The government is wary of the potentially costly and time consuming claims for compensation that would arise if cash crops had to be removed. Many blockholders have returned to Matupit and 
their blocks remain virgin rainforest. This has led to increasingly vocal demands for these blocks to be forfeited and given to those still waiting in the care centre.

In my experience a majority of the Sikut community supported the forfeit policy, as in theory did the Provincial Government Lands Division. Towards the end of my time in Sikut a concerted effort was made by the Resettlement Committee to get the Lands Division to authorise a mass forfeit of around 40 of the undeveloped blocks. When these undeveloped blocks were allocated to families living in the care centre, a series of stormy meetings took place at Sikut during which blockholders and their supporters living at Matupit would descend en masse. Blockholders who had been threatened with forfeit by the Resettlement Committee turned up to 'work' on the block for a few weeks, as a warning to the person to whom the block was to be allocated, before returning to Matupit. Many other people had hoped that the official position of the Lands Division would make this tactic impossible, but political leadership at all levels was divided. The elected Resettlement Committee was largely in favour of the forfeit policy, but they were opposed by most of the councillors, who went to the Rabaul District Government to declare the Resettlement Committee null and void. No one knew whether the Rabaul District Government or the Provincial Government' Land Division held authority over the land, meaning that any forfeit policy was likely to be held up by several years of legal wrangling.

An additional problem was that no one had previously secured title to the Sikut blocks. Most of the blocks were allocated in early 1995, with the expectation that title would be issued to individual title holders within a year. Yet at the start of 2004, no titles had been issued because the Provincial Government and the Gazelle Restoration Authority did not have the money to complete the necessary surveys. According to the Authority, this was because World Bank regulations had consistently led to delays in funding being made available. As a result of this situation, a lawyer who was sympathetic to the forfeit policy informed a Sikut meeting, shortly before I left, that the forfeits issued by the Lands Division would not stand up in court as the initial one-year temporary titles had not been renewed. Consequently, every blockholder at Sikut, whether resident or not, is legally regarded as a squatter, remaining on government land with tacit approval. Only when title was issued would the government be able to attach conditions such as block development to the continuation of that title. In spite of this situation, the Resettlement Committee went ahead with the forfeits and started moving people on to the blocks. In my last week of fieldwork in ENB in February 2004, the inevitable fights were breaking out as the original blockholders arrived to remove the newcomers.

On the surface, the current situation at Sikut may not appear to be a dispute over custom, as both sides accept that Sikut is 'non-customary' land. But the debate over forfeits has inevitably become, at least in part, a debate about the 
role of custom in land matters. Often in debates about the appropriate use of land at Sikut the phrase 'it's not customary ground' would be used as counter-claim. It was argued by supporters of the forfeits that their opponents (deliberately) failed to understand the difference between land that was given by state licence, whose continued ownership was contingent upon development of that land, and customary land that was held by clans by virtue of an inalienable right, or kakalei (Epstein 1969: 131). In these arguments the word 'custom' was used in an entirely negative sense as the alleged recourse of those who were too 'lazy' to develop their state land. The opponents of the forfeit policy did not ever claim to consider Sikut to be customary land, but some of their counter-arguments did draw on practices that most people would consider to be customary. Part of the rationale of the resettlement program was the anticipation that blocks would be developed in the bush at Sikut so that, in the event of another eruption, the displaced people of Matupit would be able to go and stay on blocks at Sikut that they had developed, or with kin who had developed blocks. This was because it was custom among the Tolai to go and stay with kin and seek assistance from them in times of need. The original distribution of Sikut blocks followed the council ward divisions of Matupit, meaning that there was a tendency for members of certain clans or people who had other close customary kinship relations to be situated near to each other. This pattern was arguably put at risk by forfeits that gave priority to residents of the care centre, and this is what prompted objections from some opponents of the forfeit who argued that breaking such patterns jeopardised customary networks of assistance in case of emergency. They argued that if forfeits were truly necessary then the blocks should be given to relatives of the original blockholders to preserve these networks. Although it is accepted that the land is not customary, according to this argument it is still important to take custom into account in the governance of this land.

This kind of argument was not just made by opponents of the forfeits. The wave of forfeits that occurred towards the end of my first fieldwork period was spearheaded by ToPirit, the chair of the Resettlement Committee. At the meeting in Sikut at which he announced that the forfeits were going ahead, Pirit raised another issue, namely the need to correct the inequity that had occurred in the case of large families, where the men had all been given blocks but their sisters had not. Later Pirit told me that the purpose of trying to ensure that sisters also received blocks was to keep clans together. In addition, he was concerned that the young men of the clan would become angry if there were no road open to them to inherit land. More important, however, was his concern to keep the clan together as a kind of social security network. He acknowledged that some people at Sikut said that the clan should become a thing of the past, and that individual families should be self-sufficient. However, he believed that this kind of 'Western' self-sufficiency would never be an option for most Papua New 
Guineans, and that even those people who had told me they would not help their nephews would still feel obliged to do so if pushed. Pirit felt that the continuation of this kind of custom was still going to be essential for years to come, and he saw tweaking the land tenure system as a means of encouraging its survival. He argued that this would ensure that people lived close to at least some members of their own clan and to other people who had been 'fathered' by their clan, thus ensuring that these relationships were of daily importance to them and strengthening the bonds of reciprocal assistance. Again, although the non-customary nature of the land is asserted, it is combined with a concern that the way non-customary land is administered can help to preserve at least some elements of what is considered to be customary.

\section{Does Custom Hold Back Development, or Is It 'Fading'?}

The widespread enthusiasm of Sikut residents for the new land as 'freeing' them from the obligations, constraints and disputes inherent in customary land, is taken by some politicians and government officials as evidence that a more general reform of customary tenure would act as a spur to development. There has indeed been significant investment and development in some of the blocks. Some blockholders have planted thousands of cocoa trees and are anticipating an income of several thousand kina a month (dependent of course on price fluctuations and crop success). Yet we must add some caveats to this development success story. Individual tenure requires the state to have the resources and will to support it if tenure is to be more than a piece of paper. The inability of the state in ENB to provide title even after 10 years, and the lack of clarity as to which of the competing arms of government has jurisdiction at Sikut, has directly led to the under-utilisation of large amounts of Sikut land. People who have been allocated blocks more recently are wary of putting too much effort into developing the land as they have seen others lose their blocks to the original landholders.

An example that illustrates the shaky basis of government jurisdiction is the road access to the blocks at Sikut, where one of the two main roads is only sealed half way. This is because, in 1995, despite warnings to the contrary, one of the blockholders planted cocoa seedlings close to the edge of his block. When the time came for the road to be sealed, he demanded several hundred kina in compensation from the Division of Works, which was going to remove his seedlings so that the road could be sealed. Exasperated by the prospect of wasting years and thousands of kina on legal action, the Provincial Government reallocated the money to another resettlement scheme. As a consequence, the blocks further away from the centre of Sikut are now serviced by a dirt track. Buses refuse to traverse the dirt track as the damages result in prohibitive costs for spare parts. Blockholders cannot afford to hire vehicles to take their cocoa to selling points, with the result that these blocks are among the least developed 
in the resettlement area. In theory, as this was government land, not customary land, the government could have removed the cocoa seedlings and continued with the road development. In reality, however, they could not afford the legal costs nor have the police tied up in resolving this situation. This example illustrates the difficulties facing the government in enforcing requirements for project development on land over which they have title, and that leaves serious doubt over the government's ability to enforce tenure reform on customary ground.

It is also worth bearing in mind that individual title, in and of itself, does not free one from the demands of kin or from customary obligations that many see as a disincentive to development. While extensive development has occurred at Sikut, no one has planted their entire three hectares with cash crops and food; the maximum planting level has been around two hectares. The reason frequently given for partial block plantings is the need to avoid constant requests for assistance or the risk of being victimised as a result of jealousy. With increased plantings, relatives calculate the future gains from produce sold and hence increase demands for assistance. As one blockholder put it, 'if they see me harvesting all the time and I don't give to some people they can do some things to my block and my cocoa won't bear fruit'. Although this problem is not as bad as it was 20 or 30 years ago, several informants told me that people who consistently refuse requests can end up dead or injured because of sorcery that is nearly always inflicted by jealous siblings or cousins. The previous chair of the Resettlement Committee (before Pirit) was one of the few who consistently attacked this belief about family interference, yet his credibility in the village in this respect was undermined by chronic arthritis in his left leg, which was seen by many as being caused by the jealousy of someone having magical power.

Most important of all, the granting of individual title will not guarantee against the re-emergence of tenure practices that many would describe as 'customary'. There is a precedent for this in ENB. In the 1950s, the Australian Administration released several large blocks of land at Wudal for lease to individuals from Tolai villages near Rabaul. These leases came with the guarantee of individual title and a policy that the land was to be inherited by the next of kin - ideally the children of the blockholder. In most cases, however, the land stayed within the blockholder's clan, often passing on to his sisters' sons, as would be the case with customary land. Although the majority of Tolai are adamant that this is 'new land', and it is morally right that the children of the blockholder who had put in all the hard work of development should inherit it, the strength of kinship ties makes it hard to refuse nephews of one's own clan when they ask to be allowed to help out on the block and plant a section of it for themselves. In such situations, when there are many working the land, it is even harder to remove them. In most cases the nephews have ended up in possession of the block after the death of the original blockholder. In theory, 
they could be legally removed. In practice, however, it is a process that can take decades and cost thousands of kina, which is not a realistic option for most Tolai. A plaintiff would probably have to wait several years before the case was heard by a local land court, and any case heard in a local land court would be liable to appeal in a higher court. There are three blocks at Wudal that were given to Matupi. Of these, two are now inhabited by nephews of the same clan as the blockholder. In only one case have the children managed to assert their legal right to inherit the title. ${ }^{2}$

Many Sikut residents will argue that Tolai society has changed since the 1960s. They argue that the nuclear family is stronger today, and that the large numbers of people at Sikut (compared to Wudal) will make it possible for a culture to emerge in which demands by clan nephews will be easier to resist. Although people never refused to recognise their nephews, I observed many occasions on which clear boundaries were drawn around the relationship especially the nephews' rights to come and stay on the block for extended periods. This is important as traditionally, in the matrilineal system, the relationship between a boy and his maternal uncle was seen as being in many contexts more important than a boy's relationship to his father, and uncles and nephews were expected to spend as much time as possible together. Now the fear of a land grab means that uncles try to limit this relationship and the amount of time that nephews spend on their block. Many people held strong views about this, including one Sikut blockholder working at one of the big mines elsewhere in PNG:

Now custom is fading away. What happened at Wudal won't happen here. Sometimes the nephews do just take over. But that can't happen now. You've got no right to come and just grab the land from my family. Why do I have to grow my kids? Why do I have to settle some place? This custom from the past is no good. Our ground is clan ground, but my ground is my ground automatically. I will never give it to the clan - no way. This kind of thinking is just for the old or the ancestors, now we've been to school we've got better ideas. If I develop this ground with my children? With my sweat? I'm just going to come and let the nephews kick them off?! No way. Not now! Why should I bother getting married? This kind of thinking is bloody rubbish and bullshit from before ... The nephews won't be able to put demands on the kids just because the father was the same clan. It's different now. The kids will be able to get a bush knife and chase them away! My kids haven't seen a cousin come and help, and if they come and ask, I'll tell them no way. If the nephews take over, the people today see it's no good. You're

2 Fingleton (1985) gives a fuller discussion of the emergence of this tendency in the resettlements of the 1960s. 
making the man's family suffer. If I behaved like this on clan land, of course there would be talk, and yes at Wudal it happened, but this generation we've seen it's not good. Because the father raised the children. The father planted the cocoa. It's not the nephews'. It's not the clan's.

I was continually struck by the strength with which these feelings were expressed at Sikut. Although there were some who felt that customary tenure would re-establish itself as it seemed to have done at Wudal, they were a clear minority. Although it is early days, in the majority of cases where blocks have been transferred as a result of death or choice it has gone to the original holders' children or other relatives outside the clan. Perhaps the most vitriolic dispute that I encountered at Sikut was between a sister and brother. The block was in the name of the mother, who initially allowed her daughter to live on the block. Several years later she decided to remove the daughter and give the block to her son. This action was believed to be motivated by an intense dislike of her daughter's husband. As the daughter and her husband had planted hundreds of cocoa seedlings and erected a permanent house, the mother's actions led to a very heated dispute. Without going into the details of the dispute, many Sikut residents remarked that the mother's original arrangement would have ensured that the land stayed in her clan for the next two generations. By attempting to remove her daughter and replace her with a son, she was, in one person's words, 'giving the land away'. Many Sikut residents saw her actions as evidence of a new attitude developing towards kinship and land tenure on state land.

\section{Buying and Selling Land at Matupit: Can Customary Land Be Alienated?}

If the allegedly individual and discrete nature of blockholdings at Sikut is potentially complicated by the tendency of customary ways of thinking and acting to creep back in, then it is perhaps also the case that ownership of customary land back at Matupit has also been complicated by Tolai responses to new economic circumstances. Debates around land tenure in this part of ENB have long centered on the issue of patrilineal versus matrilineal transfer of rights, with many associating patrilineality with a positive move towards 'modern' land tenure systems. Most of PNG, however, is classified by anthropologists as having 'patrilineal' customary land tenure. What is fundamentally at stake in these debates is an argument about the alleged economic advantages of removing interests in land from cycles of ongoing customary obligation and reciprocal social relations, and instead making land the alienable property of individual persons or household units. In the matrilineal Gazelle, the distinction between matrilineal and patrilineal inheritance has understandably largely come to stand for this debate, with a shift to patrilineality representing the removal of clan-based reciprocal obligations. However, the ways in which Matupi negotiate 
these tensions today show that characterising land as customary or non-customary is a far from simple matter.

At Matupit today a large proportion of houses are built on purchased land. It is particularly common for fathers to buy land from their own clan to overcome the problems that will arise between their children and their nephews if they build permanent houses on their own clan land. The buying and selling of customary ground is in theory illegal in PNG, unless the buying and selling can be shown to be a customary practice. The custom of 'buying' ground is known among the Tolai as kulia. However, Bill Epstein, who conducted fieldwork at Matupit in the early 1960s, was keen to stress that kulia does not neatly equate with the Western idea of an alienable commodity transaction, noting that, ' $[t]$ he indigenous concept of $\mathrm{kul}$ then is translated by the term purchase only at the risk of serious misrepresentation' (Epstein 1969: 132). Epstein devotes some attention to what distinguishes kulia from Western ideas of buying and selling, as for him the different nature of this transaction is key to illuminating the ways in which Tolai customary land tenure differs from Western property regimes.

In the indigenous system land was not a commodity. Transfers of land were not conducted according to the principles of the market; rather they were effected between parties who saw themselves as already linked by social bonds, and when land was exchanged in return for tambu it was usually in recognition of the obligations of kinship or other customary claims ... the payment demanded in tambu was also small. This remains the position today in regard to 'sales' of land within the village, where the sums involved in cash and tambu fall very far short of the market value (ibid).

Two reasons are given here for why kulia should not be considered equivalent to Western commodity transactions. First, there is the nature of the bonds preceding the transaction, implying that kulia should be seen as a part of an ongoing cycle of customary obligation rather than as a stand-alone purchase of alienable property. Second, the low level of payment, 'short of the market value', is provided as evidence that the payment is 'in recognition of ... customary claims' rather than an outright purchase. ${ }^{3}$

The conclusion that Epstein draws from this state of affairs is that the kakalei or 'claim' to the land 'remains vested in the vendor lineage' (Epstein 1969: 104). This non-alienability of claims in the land is a key difference between Tolai customary land and Western landed property. ${ }^{4}$ I have been told that in the past

\footnotetext{
3 These two observations are backed up by Fingleton in his (1985) study of land tenure at the nearby Tolai village of Rakunat during the mid 1980s.

4 See Mauss (1970) and Gregory (1982) for key discussions of the central importance of the non-alienability of objects in Melanesian societies in contrast to Western conceptions of alienable property.
} 
there would often be expectations that the land might return to the vendors at some point after the death of the buyers, that they would be considered to have an ongoing relationship with the piece of ground, and that if the 'purchasers' failed to be suitably attentive to their ongoing customary obligations to the vendors then it would be commonplace for the vendors to find a way to reclaim the land. However, even by the early 1960s, Epstein had identified trends that were taking kulia away from this customary ideal. First, the increasing number of land deals with the colonial administration and the large amounts of money involved meant that the clan elders who controlled the land were 'now encouraged to think of land increasingly as a commodity' (Epstein 1969: 132). The young men who protested at many of these deals were essentially claiming that the elders 'had no power to dispose of the land so as to remove it from the sphere of Tolai social relationships and customary obligations' (ibid). Second, cash cropping meant that 'many Tolai are beginning to find it necessary to think of land as a commodity even in transactions among themselves' (ibid). Epstein cites the example of a young man who bought a plot of customary land in the village of Napapar to plant cocoa. When his cocoa was ready to bear fruit, they reclaimed the land. Epstein concludes that '[f]or him, as for many Tolai, the traditional system of land tenure was beginning to reveal its limitations in meeting the needs of contemporary situations' (ibid: 133).

Today, I would argue that although kulia retains features that distinguish it from the purest ideal of commodity transaction, it has continued to change in many respects. Radin (1996) suggests that what is referred to as 'commodification' is necessarily an incomplete process, and whether a thing, transaction, or relationship should be viewed as a commodity is therefore a matter of degree, rather than an 'either/or' distinction. In my opinion, changes to kulia over the past 40 years can be usefully looked at in this way. Parties to the transaction will tend to be involved in ongoing customary relationships, as almost everyone at Matupit is involved in customary relations with everyone else anyway. Fingleton notes that the flexibility of relations in the village makes it easy to construct customary ties that legitimise a kulia transaction: 'no land transaction may be mounted without a pre-existing link between the parties, but the relativity of Tolai concepts of group corporateness and kinship facilitates the establishment of a connection between willing people' (Fingleton 1985: 211). This means that even outsiders with no history of relationship to the community can buy land in the village through the creation of customary ties. Although I was unable to observe the purchase of any land during my time at Matupit, I was told that it was not hard to accomplish. Even as early as the 1960s a number of settlers from the Sepik area had bought land on the edge of Matupit, and their descendants were still living there when I was doing fieldwork. Fingleton makes a convincing case that this plasticity of customary relations is an example of the inherent flexibility of customary tenure that makes it better adapted to rapidly 
changing social relations than fixed Western property law. From a theoretical angle however, this inexhaustible flexibility can be problematic, because if customary culture is so flexible that it can encompass any kind of relationship then it is at risk of becoming a tautological concept that defines and prescribes nothing.

I found that there were regular disputes as to how customary some manifestations of custom really are, the most frequent examples being criticisms of economically powerful 'big-shots' for 'commercialising' custom. Custom is at least partly judged by whether or not one's actions are considered to be embedded in and constitutive of the kind of customary reciprocal relations that Epstein's young men accused the elders of abandoning by selling land to the Australians. Even if one performs custom as a set of rules perfectly, one's actions can be considered to be fundamentally non-customary when judged on this basis. This contrast between custom based on ongoing reciprocal obligations, and Western social life as being based on business transactions, although far from exhausting the multivalent possibilities of the word 'custom' or kastom, was an often repeated and important part of the definition. If Radin is correct to say that commodification is a necessarily incomplete process, and Gregory (1982: 23), drawing on Sahlins, is correct in arguing that, 'the distinction between gift exchange and commodity exchange should not be seen as a bipolar opposition but rather as the extreme points of a continuum', then the networks of social relations that go into making up a transaction can be viewed from more than one angle, and indeed often are viewed as part of a process of assessing the morality of these transactions.

The danger in simply describing the ease with which customary relations can be created to make kulia possible is that this can assume what it seeks to demonstrate - namely, the fundamental difference between kulia as a customary practice and standard Western property transactions as an empirical 'bipolar opposition'. Just as it is possible for Matupi to view the involvement of big-shots in custom from an angle that declares it to be non-reciprocal and therefore not truly customary, it is also possible that customary links which are so easily and flexibly contracted can be seen from certain angles as a kind of preparation for a kulia transaction that now looks more like a purchase. Kulia may be formally the same as before, but its increasing relative weight and degree of finality may make it appear, in certain indigenous descriptions at least, more like a commodity transaction for which the preceding transactions are preparatory work, rather than part of an ongoing cycle of customary reciprocity. Certainly the description of how custom can 'hide' the true value of a transaction suggests that this is one possible indigenous perspective from which kulia can be described today. Some transactions sit so clearly towards one or the other of Gregory's two poles that the scope for different perspectives to be taken on them is severely limited, but others are more ambiguous. I would not argue, against Fingleton and others, 
that kulia is a commodity transaction and therefore that Tolai think of land in the same way as Australians. Rather, my argument is that kulia is not simply an uncomplicated customary transaction, but can also be viewed as embodying other, less customary, more commodity-oriented ethics. Changes over the past 40 years, while not totally 'commodifying' the transaction (and by implication Tolai attitudes towards land), have moved it further towards that pole of the spectrum by creating more situations in which Tolai find it fruitful to describe land in property/commodity terms. This is perhaps the very process by which partial commodification occurs.

Epstein and Fingleton (especially the latter) do not just stress the importance of establishing customary connections prior to kulia, but also the maintenance and continued recognition of these links after the transaction. For example, after noting the flexibility with which customary connections legitimising kulia may be created, Fingleton goes on to say that:

the connection, however, whether direct or indirect, forms the basis of the land transaction. It characterises the tenure thereby gained, so that its security remains indefinitely dependent upon maintenance of the formative connection (Fingleton 1985: 211).

Although it is the case that there is still a tendency for kulia to be transacted between persons or groups who were already strongly linked - as when a man buys from his own clan on behalf of his children - I found no evidence that kulia transactions tend to strengthen the connections, and in some cases there is little or no ongoing relationship.

One of my closest acquaintances built his house on land that he bought from the last male representative of one of Matupit's major landholding clans. This purchase was made in 1983, and to my knowledge the purchaser has had no ongoing customary relationship with the vendor, and would give him very short shrift if he came to ask for favours or gifts on the basis of his ancestral links with the land upon which the purchaser has built his house, which is something that vendor is wont to do with some people to whom he has sold land. What is interesting is the attitude of the majority of Matupi to requests such as this. Most people say that it is dishonest as it is an attempt to get money 'twice for land that you have already sold'. In many contexts in contemporary PNG, such as negotiations with a mining company, landowners are keen to demand the establishment of an ongoing and more customary relationship that goes beyond single payments because of the other party's long-term presence on the land. Amongst Matupi, however, the idea that a transfer of land can be a way of legitimising such demands is treated with near-universal incomprehension or repulsion. It is clear that Papua New Guineans do not view land transfers according to a logic of inexorable commodification, or according to an unchanging cultural logic of inalienability, but instead are as capable as any other group of 
people of judging (or disputing) that different kinds of transactions are morally appropriate in different contexts.

\section{Registration of Landownership and Transfer}

How do Tolai people now respond to the statement made by Epstein that kakalei remains with the vendor clan even after kulia (sale). In 2002-04, the response was universally one of incredulity. People would assert that of course kakalei can be transferred, there would be no point in buying something if you didn't receive the kakalei. This would sometimes be followed by the suggestion any statement to the contrary must be the work of crooked old men who want to get money twice for the same piece of land. Epstein notes that sale by kulia never gives secure ownership as it only takes one member of the vendor clan to stand up a couple of years later, and claim not to have been consulted, for the sale to be undone (Epstein 1969: 131-2). Epstein implies that this is one of the ways in which kakalei remains with the vendor clan, like the case in which the purchaser is remiss in maintaining an ongoing customary relationship with the vendor after the kulia transaction. Today, this 'problem' has been partially resolved by a practice that has evolved over the past 30 years, of witnessing the purchase with a statutory declaration which all adult members of the vendor clan must sign before the deal is finalised.

The practice of witnessing purchase with a statutory declaration started in this part of ENB under the Australian Administration in the early 1970s, although T.S. Epstein's fieldnotes include government records of land purchases in the much less 'developed' Tolai village of Rapitok during the late 1950s.' According to Jessep (1980: 123-4), the recording of land sales in ENB was 'apparently valued for the documentary evidence of the sale and the publicity of the payment made at the office'. Fitzpatrick (1983: 19) cites Tolai evidence in support of a wider argument about PNG in the 1970s:

Unofficial and semi-official land registers ... had emerged ... [U]nofficial transfers of land as a commodity were taking place between members of different groups. Various operative strategies had developed to restrict the range of obligations effective in succession to land, to increase individual control over the process and to confine transmitted rights more to the nuclear family or a favoured son. Nor were these trends without suggestive precedent in the customary base ... With the extension of cash-cropping after the second world war ... there emerged a greater awareness of land as having a reified value and greater, and effective, pressure for more clearly defined individual rights in land.

5 T.S. Epstein's fieldnotes are held in the Mandeville Special Collections Library at the University of California, San Diego. 
I was often told that if you have 'the paper' (meaning the statutory declaration), then you are safe. One old man explained to me that 'before we did not know how to buy and sell properly; now that we have the paper, we have more save (knowledge)'. This clearly indicates the perception that the nature of kulia has changed over the years. In this context, as one person described it to me, 'papers' do have power to 'strengthen' the practice of buying ground, and this is part of the process that Tolai have developed in response to their perceived need to secure land that they were buying for their children. Hence, paper 'kills the talk' on a piece of ground - at least between the selling clan and the buyer - although there is always the option for a third party to claim that the vendors never had the right to sell the ground in the first place.

I have no personal experience of the selling clan reclaiming land from a buyer who had a statutory declaration. Of course a registration can be misleading to the outside observer, conflating a number of reciprocal customary obligations into one simple transaction (Fingleton 1985: 184-6). However, registration of the purchase transaction, in Matupit at least, does seem to set a kind of seal on the land transfer, making it harder for alleged oversights in the recognition of ongoing obligations to be used to overturn the transaction. Even if, in many cases, land transfers are unimaginable without a preceding history of relationships and anticipation of ongoing relations, the act of registration does seem to give the transfer a degree of separation from these relations.

The use of statutory declarations is now semi-officially recognised by the Provincial Government: the Lands Division keeps copies of all land purchase statutory declarations and has also put in place official guidelines for the practice. All reports of the origin of this practice claim that its impetus came from the village not the government. According to Fingleton (1985: 181-2), the practice began in Rakunat as a continuation of an aborted attempt by the colonial government to register land in the 1960s, and was carried out by the villagers themselves in order to secure land transfers, not as part of a government plan to reform customary land practices. As he puts it, '[t]he most important changes in ... land tenure ... are those which occurred internally, in transactions within the village community which continued the process of adjustment to changing land demands' (ibid: 178). This is an important point because great attention is often paid to a history of unsuccessful state-driven changes in land tenure imposed upon an unwilling population, as it was in the case of the Gazelle Peninsula (ibid: iii). This ethnographic description fits into what has become a wider theoretical concern in recent years, namely the ways in which the state needs to organise its subjects and their practices in ways that enable it to 'see' and therefore govern them more efficiently (Scott 1998). It is understandable if this history is emphasised to counter the misguided arguments of those who suggest that Western nations should use their disproportionate economic power to force Melanesian nations into land tenure reform. But it is also important to 
acknowledge that, in an engagement with the global economy in certain contexts, Melanesians are bound to explore the possibility of different ways of transacting land, and that sometimes they will seek the support of the state in making these more secure. To acknowledge that it is just as possible for the state's subjects to be recognised in a manner that fits their needs, as it is for the state to demand that its subjects be organised in a manner that makes it possible for the state to 'see' them, should in no way be taken as an endorsement of overarching schemes to revolutionise village life through legislative action. Quite the opposite: it shows the importance of a careful ethnographic attention to the different details of processes of contested commodification as they occur in different circumstances.

Land that is transacted by this process is still legally considered to be customary land, and although the purchaser, if a man, has the right to pass it on to his children, in the next generation it must follow matrilineal principles. ${ }^{6}$ For this reason Matupi will tend to refer to even 'purchased' land at Matupit as customary land, largely in contradistinction to their land at Sikut. However, they are also clearly aware that the custom of kulia and its relationship to wider networks of customary obligation has changed in some respects in the past 40 years. Land disputes at Matupit are not as widespread as they were in the years leading up to the volcanic eruption of 1994, but it was notable that not one of the cases I observed was an attempt by vendors to overturn a land sale that had been registered, and I was told by most Matupi that any such attempt would be fruitless. The Lands Division and the majority of Matupi clearly view kulia today as a transaction that implies the complete alienation of all rights in a piece of land from one group to another. Epstein's claim that 'the estate vested by a "purchase" is always regarded as inferior to a kakalei' (Epstein 1969: 131, my emphasis) has, at the very least, been complicated by changes to Tolai kulia over the past 40 years.

With regard to 'market value', I conducted a village household survey and discovered that the average 'price' paid for a house had hardly risen at all in the past 40 years. This was in contrast to the prices of other essentials, such as imported foodstuff and materials used to build permanent houses, which had risen dramatically. Although what constitutes 'market value' is hard to ascertain in an environment such as Matupit, prices as low as K50-100 (equivalent to the cost of two cartons of beer) seems good value for the outright purchase of a plot of land on which one is going to build a house that will cost thousands of kina. This stability seems to bear out Epstein's original observations about the non-commodity nature of customary land transactions at Matupit, and to cast

6 This means that it will most likely go to the children of the purchaser's daughters, so if a man buys land from his own clan for his children, the land passes from his own matriline to a section of his wife's matriline. 
doubt on his prediction that trends were emerging in village life that were going to push land transactions in a more commodified direction. Matupi offered a number of explanations for the relative stability of land prices. One was that land had for a long time been a part of the customary system, although that answer was always accompanied by a caveat that this was changing and that prices for land were starting to rise. Indeed, I was often told that the volcano had stopped an anticipated explosion in land prices, just as it had stopped the explosion of land disputes. Another response was that many of the prices that I had been given during the course of my village survey were most likely exaggerated as many of the prices were much higher than I had been led to believe. People would publicly 'buy' the land for a small amount of money, but behind the scenes, hundreds or even thousands of kina (or equivalents) would change hands. The larger amounts would be kept secret. It is worth pointing out that there were some at Matupit who angrily denied that such a thing could happen, but the very suggestion demonstrated an awareness on the part of some Matupi that there was something of a contradiction here. On the one hand, the legal registration of a seemingly commercial transaction can mask a web of customary obligations; on the other hand, the low monetary value of a seemingly customary transaction can mask a commercial exchange of greater value. Indeed, a few people told me that custom was a means for 'hiding' the value of a land purchase, once again demonstrating that seemingly customary transactions are capable of being viewed from a commercial perspective if one wants to cast them in a certain moral light. We are familiar, in Melanesian ethnography, with a position that stresses how relationships that have seemingly been Westernised or commodified are, on closer examination, still based on a customary ethic of reciprocity. This is undoubtedly often true, but perhaps in stressing such moments we sometimes lose sight of the logical corollary - situations in which what on the surface appears customary and reciprocal can simultaneously embody the opposite ethical values. The ways in which Matupi discuss the 'commercialisation' of custom demonstrates that they have certainly not lost sight of these possibilities.

As well, there are tendencies emerging at Matupit today that suggest a more openly commercial attitude towards land sales. During my last visit to Matupit I interviewed a village councillor about land sales in his ward. He told me of a woman who had sold three separate plots of land for houses in the village on behalf of her clan section in the past year. Instead of the one- or two-hundred kina standard land sale price on my village survey, she had sold land for K2-3000, a price much closer to the amount that similar plots would receive on the commercial market in Rabaul. The councillor stressed that such price rises were the result of land registration, and that meant that the purchase was secure. From the point of view of the state and Matupi themselves, although the land remained customary, in contradistinction to the land at Sikut for example, it 
clearly does not live up to certain ideals of custom as these are expressed in many ethnographic and indigenous accounts.

The performance of customary ritual has always been of great importance to people's rights to reside on certain pieces of land. A man wishing to stay on his father's clan land after his death would pay close attention to helping his father's clan in custom, in particular distributing large amounts of customary shell-wealth on his death. Even someone residing on his own clan land would not expect residence by right, but would be expected to help in custom. Someone remiss in their customary obligations would bring shame on the clan and would likely be given the worst pieces of ground to live and garden upon. Today the picture is slightly different. The declining power of the big men in the clan means that complaints about young men simply building a house on clan land without consultation with elders of the clan are not uncommon. Members of the Matupi community at Sikut have begun performing customary practices from Matupit, such as the namata, a kind of initiation for the first-born son of a family. One of the minority of Matupi who hoped for a return to openly full-blooded 'customary' land tenure at Sikut told me that this emergence of custom at Sikut was a sign that his hopes would be realised, just as had happened at Wudal. He was also of the view that the Provincial Government's attempt to remove customary clan relations from land tenure at Sikut was a continuation of the Australian Administration's attempts to 'turn us into white men' when they tried to enforce patrilineal nuclear family inheritance at Wudal. For most Sikut residents, however, the extent to which the performance of custom heralds the re-emergence of customary land tenure is not clear. As one young male resident at Sikut explained to me in October 2002: 'When you do custom at Matupit you are concerned with land. When you do custom here it is custom only (tasol).' He further argued that many Matupit residents who had been heavily involved in custom before they got blocks at Sikut were now involved in the bare minimum required for social respectability. Now that they had their own land, they no longer felt the need to keep the clan happy by performing custom.

Whatever the future holds at Sikut, these examples show that there are problems in defining land as customary or non-customary, and that these may sometimes be overlooked in policy debates. The land at Wudal is still formally regarded by the state as non-customary land, yet it is widely acknowledged to be land where 'custom has come back in' to the extent that many people describe it as 'like customary land' or even as 'customary land'. The increasing performance of custom at Sikut, along with trends to acknowledge the importance of customary relations on non-customary land, may well have effects on land use and occupation. The question is how much effect will it have, and how much will be necessary for the inhabitants to acknowledge that the land has become de facto customary. Conversely, the land bought and sold by kulia at Matupit is still in the eyes of both the state and Matupit 'customary', yet it is described 
in ways that make it appear less customary, according to certain glosses of the word 'custom', than would have been the case 40 years ago. Custom is as much a position taken on the morality of certain transactions as it is an empirical description of a juridical process to be preserved or reformed in the interests of national development.

\section{References}

Bradley, C.B., 1982. Tolai Women and Development. London: University College London (PhD thesis).

Epstein, A.L., 1969. Matupit: Land, Politics, and Change among the Tolai of New Britain. Canberra: Australian National University Press.

Epstein, T.S., 1968. Capitalism, Primitive and Modern: Some Aspects of Tolai Economic Growth. Canberra: Australian National University Press.

Fingleton, J.S., 1985. Changing Land Tenure in Melanesia: The Tolai Experience. Canberra: Australian National University (PhD thesis).

Fitzpatrick, P., 1983. 'The Knowledge and Politics of Land Law.' Melanesian Law Journal 11: 14-34.

Gregory, C., 1982. Gifts and Commodities. London: Academic Press.

Jessep, O., 1980. 'Land Demarcation in New Ireland.' Melanesian Law Journal 8: 112-133.

Mauss, M., 1970. The Gift: Forms and Function of Exchange in Primitive Societies. London: Cohen and West.

Radin, M., 1996. Contested Commodities: The Trouble with Trade in Sex, Children, Body Parts and Other Things. Cambridge: Harvard University Press.

Salisbury, R.F., 1970. Vunamami: Economic Transformation in a Traditional Society. Melbourne: Melbourne University Press.

Scott, J., 1998. Seeing like a State: How Certain Schemes to Improve the Human Condition Have Failed. New Haven: Yale University Press.

Smith, S.S., and R.F. Salisbury, 1961. 'Notes on Tolai Land Law and Custom.' Unpublished report to the Native Land Commission, Kokopo. 